\title{
Spillover Effects from Unintended Trials on Attitude and Behavior: Promoting New Products Through Access-Based Services
}

\author{
Adrian Lehr \\ Institute of Marketing \& Management, University of Hohenheim, \\ Schwerzstr. 42, 70593 Stuttgart, Germany, \\ Email: alehr@uni-hohenheim.de
}

\section{Marion Buettgen}

Professor for Corporate Management, Institute of Marketing \& Management, University of Hohenheim, Schwerzstr. 42, 70593 Stuttgart, Germany, Phone: +49 (0)711 459 22909, Email: buettgen@uni-hohenheim.de

\author{
Sabine Benoit* \\ Professor of Marketing \\ Department for Marketing and Retail Mgt., Surrey Business School, \\ Guildford, GU2 7XH, UK and
}

College of Business and Economics at Australian National University (ANU), Canberra ACT 2601, Australia

Tel.: +44 (0)1483 68 6338; Email: s.benoit@surrey.ac.uk

\section{Katrin Merfeld}

Postdoctoral Researcher, Department of Marketing, EBS University for Business and Law, Gustav-Streesemann-Ring 3, 65189 Wiesbaden, Germany, Phone: +49 (0) 6617102 1464, Email: katrin.merfeld@ebs.edu

* Corresponding author

\section{Acknowledgments}

The authors thank the corporate partner for this research, stadtmobil, for its excellent cooperation and support of this field study. They thank the attendees of the Frontiers in Service Conference, whose comments helped further develop the project and Thomas Baker for providing a friendly review of a prior version of the manuscript and Vukasin Gligoric for his support in the data collection of the second study. 


\title{
Spillover Effects from Unintended Trials on Attitude and Behavior: Promoting New Products Through Access-Based Services
}

\begin{abstract}
Access-based services (ABS) provide an opportunity for brands to promote their new products by enabling (unintended) trials. However, the mechanisms and impact of consumer exposure to products in ABS and the subsequent potential spillover effects on both the brand and the product perception are largely unknown. Our hypotheses are derived from information integration theory (IIT) and subsequently tested. Study 1 is a field study investigating an unintended trial moderated by involvement and positive experience. The results indicate positive effects from the unintended trial on product and brand attitudes, brand purchase intention, and word of mouth. In line with IIT, these effects are more pronounced for positive trial experience, although in contrast to IIT, they are less pronounced for high involvement consumers. While the results of Study 2, an online experiment, show substantial effects of both trials compared to non-trials, they also reveal that intended and unintended trials have a similar impact on attitude, but ABS experiences have a stronger positive impact on brand purchase intention. We thus recommend that brand managers promote not only new products but also their brands in unintended trials. This research fills a gap in current discussions about the trial effect(s) of ABS.
\end{abstract}

Keywords: information integration theory, trial effects, unintended trial, access-based services, field study, e-mobility, attitudinal change, word of mouth (WOM), involvement

Article Classification: Research paper 


\section{Introduction}

Offering potential customers a direct experience with a product and its attributes, e.g., through a trial, can be an effective albeit costly method of introducing a new and innovative product onto a market (Wright \& Lynch Jr, 1995). This is because the information consumers gather during trials is highly diagnostic and thus trustworthy (e.g., Kempf, 1999; Daugherty, Li, \& Biocca, 2008). Commonly, trials are conducted with the explicit intention of gathering information about a product, for example, during a purchase-decision process (e.g., Kempf \& Laczniak, 2001), but they can also occur unintentionally, for example, by experiencing a product during a service (Bednall, Oppewal, Laochumnanvanit, \& Nguyen, 2018; Lawson, Gleim, Perren, \& Hwang, 2016). Such unintended product trials happen regularly during "access-based services" (ABS) that offer consumption options including temporary access to a physical good (Baumeister, Scherer, \& Wangenheim, 2015).

The relevance of ABS has grown recently with the rise of the sharing economy and the consequent consumer preference for access over ownership (Benoit, Baker, Bolton, Gruber, \& Kandampully, 2017). Figures from the mobility segment alone provide evidence of the potential growth and significance of the market for ABS: up to 8 billion EUR market size for the global bike sharing market in 2021 (Roland Berger, 2018) and 36 million carsharing users in 2025 (Frost \& Sullivan, 2016). Some manufacturing companies are already seeking to capitalize on the trend toward ABS either as an alternative revenue stream or as a mode of experiencing their products. For example, Audi cooperates with the car-sharing service Miles so that consumers can try out their e-cars, and the camera manufacturer Nikon offers services to access their equipment for events, allowing users to try out the equipment. However, since consumers are usually assumed to regard ABS as an alternative to purchasing the accessed product, many manufacturing companies see ABS as a risk (Schaefers, Lawson, \& KukarKinney, 2016). 
Insights on whether companies should engage in ABS to promote their brands and products is scarce since literature on the trial effects of ABS is absent (Lawson et al., 2016). Previous trial literature focuses on situations in which products are presented to subjects who subsequently evaluate them, either based on a direct experience (a product trial) or an indirect one (e.g., advertising) (e.g., Bettiga, Lamberti, \& Noci, 2017; Hamilton \& Thompson, 2007). Research has thus far neglected product trials that take place concomitantly during serviceusage situations and are therefore unintended. Previous ABS research focuses on drivers of, or barriers to, demand (e.g. Hazée, Van Vaerenbergh, Delcourt, \& Warlop, 2019). With notable exceptions (Baumeister et al., 2015; Schaefers et al., 2016), there is limited research on the actual product and its brand that the consumer is exposed to during ABS (e.g., Abrate \& Viglia, 2019). As a result, neither the research on trials nor on ABS can clarify the impact of product exposure on consumers during ABS, that is, potential spillover effects on attitude and behavior toward products and brands. It is also unclear how the specific trial experience and consumers' involvement in the product category explain a potential impact of product exposure during $\mathrm{ABS}$. In accordance with this, we aim to answer the following research question: What is the impact of unintended product trials through ABS on consumer attitudes and behavioral intentions toward products and their corresponding brands?

To address this question, we rely on information integration theory (IIT) to explain the formation and modification of attitudes and subsequent decision making (Anderson, 1971, 1981, 1991). Previous research in marketing has shown that IIT has supported the generation of valuable insights into the proposed spillover effect of ABS (Simonin \& Ruth, 1998). In Study 1, we test how the exposure to a product during ABS affects the consumer. In line with IIT, we differentiate in the choice of our dependent variables between attitude and intentions for decision making (Anderson, 1971, 1981, 1991) and between the product and the brand as two different targets of the spillover effect (Baumeister et al., 2015). We have chosen two 
relevant and resource-intensive decisions: behaviors that reflect purchase intention regarding the product and regarding the brand. To potentially also detect smaller-scale behavioral effects, we have included a non-resource-intensive behavior, word of mouth (WOM), which has also been shown to be highly relevant for purchase behavior, and more specifically the purchase behavior of others (Iyengar, van den Bulte, \& Lee, 2015). Since IIT suggests that information integration is a process that depends on the valence and weight of information, we also test the effect of these two factors. In addition, in Study 2, we compare and contrast intended and unintended trials and their impact on attitude formation and decision making to further contribute to potential spillover effects during unintended trials during ABS.

By applying IIT to our context, we intend to make three main contributions to the literature. First, this research adds to the existing literature on trials and IIT by not only distinguishing and defining, but also by testing, the effect of an intended versus an unintended trial. Whereas intended trials result from information needs during a choice process and focus on the goal of product or service evaluation (Peterson \& Merino, 2003), unintended trials are incidental. Our research thus contributes to the literature on trials and IIT by identifying and testing a new type of trial (unintended trials) in which there is no intention to integrate information and contrasting it with established types of trials by analyzing their impact on information integration.

Second, to psychology in particular, our paper adds by further elaborating on the underlying processes of information integration in unintended trials by introducing and investigating two moderators deduced from IIT. Hence, we shed light on the mechanisms for enhanced effects of information integration and thereby contribute to IIT. Specifically, in Study 1, we operationalize the valence of information as the evaluation of the trial experience and the weight of information as product involvement. Assessing both variables in a field experiment (Study 1) and supplementing it by investigating the role of involvement in an 
(un)intended trial in a scenario experiment (Study 2) contributes to a better understanding of the differential impact of both moderators on consumers' information processing and resulting behaviors.

Third, our research extends the research on ABS by investigating the potential spillover effects of an unintended trial on consumer product and brand attitudes and behaviors during ABS. We show that ABS is a highly relevant and suitable setting for (unintended) trials even though this is not an initial aspect of the business model. We thereby extend the research field of ABS by identifying a potential secondary benefit and consequence of $\mathrm{ABS}$ for both users and original equipment manufacturers. With these insights, marketing managers can leverage ABS more effectively to increase the diffusion of their new products.

Our findings show that, in general, unintended trials, i.e., being exposed to a product during ABS, have positive spillover effects on attitude and behavioral intentions toward the product and product brand, with attitude being more likely affected than behavioral intentions, in particular product-related purchase intention. The results further show that trials (intended and unintended) have a larger positive impact on attitude compared to non-trial information. Interestingly, with one exception, we did not find evidence for a stronger impact of intended versus unintended trials on attitude and behavioral intentions, suggesting that for new products, intention for information integration is negligible. The perception of a positive trial experience mostly strengthens the effect on attitude and intentions, whereas involvement has no effect or even weakened these outcomes.

\section{Conceptual and Theoretical Background}

\section{Information Integration Theory}

Information Integration Theory (Anderson, 1971, 1981, 1991) explains how individuals evaluate and integrate new information into their judgments and decision making, such that they form or modify their existing attitudes and beliefs by evaluating and integrating 
information from various sources (Anderson, 1981). The predicted process consists of three steps: Evaluate the information, integrate the information, and offer an observable response (Anderson, 1991). Each piece of information is also characterized by valence and weight parameters. Valence indicates a location on a judgment scale, and weight refers to the importance of the information to each person, relative to other information (Anderson, 1971). For example, consumers might evaluate product information positively hence they have high valence, but consider that information to be less personally relevant, such that it has low weight. Since attitudes depend on both valence and weight, the overall evaluation of the product will only change marginally.

This theory was introduced into marketing with the aim of understanding consumer evaluations (Anderson, 1971). It has been used for a variety of marketing and consumer behavior topics; for example, the evaluation of product bundles (Janiszewski \& Cunha Jr, 2004), the formation of and changes to brand attitudes as well as spillover effects that might be caused by brand alliances (Simonin \& Ruth, 1998), and coalition loyalty programs (Schumann, Wünderlich, \& Evanschitzky, 2014). Moreover, the impact of country-of-origin information and price on perceived product quality (Hastak and Hong (1991), the impact of online ratings on product evaluations and willingness to pay (Fisher, Newman, \& Dhar, 2018), and the impact of online celebrity endorsement on purchase intention (Fink, Koller, Gartner, Floh, \& Harms, 2018) have been assessed applying IIT. IIT has also served as a foundation for evaluating the effects of product trials on brand and product attitudes (Smith, 1993). Specifically, IIT provides insights into the effects of introducing ABS on brand reputation (Baumeister et al., 2015), as prior research has shown that reputation is indispensable for generating revenue in the sharing economy (Abrate \& Viglia, 2019).

One aspect that has had scarce coverage in IIT is how situational context such as the level of intention to gather information in a consumption situation (i.e., intended and 
unintended trials) impacts information integration and its results. Even though prior literature has pointed to the relevance of situational factors for information integration, particularly to the time-dependent adequacy of stimuli in the decision-making process, empirical research is scarce. For example, Carlson and White (2008) found that in the early stages of a decisionmaking process, complex information about product specifications might not be as relevant as in later stages; Kardes and Kalyanaram (1992) found that in situations of distinct preferences and limited brand knowledge, sequential information integration is beneficial; while Kim, Yoon, and Lee (2010) found that the exposure sequence of publicity messages versus advertising messages impacts attitude formation. To the best of our knowledge, the situational impact of intention on integration information has not been covered in research to date; hence, the aim of this manuscript is to fill that information gap.

\section{Trial literature}

Product trials are defined as providing a personal interactive experience with a largely unknown product (Hamilton \& Thompson, 2007). As such, a trial experience can represent a vivid and cogent learning moment, i.e., it can lead to information integration. Such multisensual trial experiences are deemed critical for consumer attitudes, intentions, and adoption behavior (Kempf \& Smith, 1998; Kempf, 1999; Smith \& Swinyard, 1983). This is partly because they are self-generated and derived from an unmediated interaction between a consumer and a product or brand, and so the source has maximum trustworthiness (Kempf \& Smith, 1998). Interestingly, attitudes formed from direct experience during trials are stronger, more confidently held, and better predictors of behavior than those formed from indirect experience such as advertising (Kempf, 1999).

Product trials in a consumer context usually take place when individuals actively seek to investigate largely unknown products which they then experience (e.g., car test drives or product sampling) (Hinsz \& Ployhart, 1998). They are thus intended product trials resulting 
from information needs during a choice process and oriented toward the goal of product or service evaluation based on the trial experience (Peterson \& Merino, 2003). Kempf (1999) accordingly argued that consumers are in an "evaluative mindset" during an intended product trial, implying heightened attention and information processing.

We argue that product trials are not necessarily always intended by consumers since they are regularly exposed to largely unknown products in consumption situations that they experience personally and interactively. In this manuscript, we refer to those experiences as unintended trials, defined as an incidental, personal, and interactive experience with a largely unknown product. Hence, in contrast to intended trials, unintended trials are not deliberate, but rather concomitant. However, the role of intention in trials has been neglected in previous research. It is therefore unknown whether unintended trials similarly shape customers' product- and brand-related attitudes and behaviors, since they should likewise serve as a reliable and trustworthy information source for products and also offer high trial diagnosticity.

\section{Access-based services}

Access-based services are "market-mediated transactions that provide customers with temporally limited access to goods in return for an access fee, while the legal ownership remains with the service provider" (Schaefers, Lawson et al., 2016, p. 571). ABS are marketmediated, meaning that the main point of contact for customers is a professional service provider rather than a peer, as in the case of an Uber driver (Benoit et. al., 2017).

Furthermore, ABS differ from traditional rental services in that they are characterized by short-term usage (Benoit et al., 2017; Moeller \& Wittkowski, 2010). In line with incidental brand encounters (Ferraro, Bettman, \& Chartrand, 2008) and unconscious product evaluation (e.g., Simonson, 2005; Dijksterhuis, Smith, van Baaren, \& Wigboldus, 2005), we argue that during $\mathrm{ABS}$, consumers undergo an unintended trial as they use a respective product without 
the intention of testing and evaluating it. Examples of unintended trials in other contexts include, for example, using a branded soap, a mattress, or a TV set in a hotel room. In the context of car sharing, an example would be the intention to use a car-sharing service while undergoing the unintended trial of, e.g., a certain brand of car.

We apply IIT to enhance our understanding of spillover effects from unintended (product) trials during ABS. Accordingly, product information obtained through ABS should be highly relevant for information integration because it is a personal and interactive experience of a largely unknown product. At the same time, the information obtained during a positive (rather than a neutral) trial experience through $\mathrm{ABS}$, which represents the valence of the information (location of the informational stimulus along the dimension of judgement), should enhance the product evaluation as a result of the information integration process (Kim \& Morris, 2007). In line with IIT, attitudinal and behavioral effects represent the central outcome variables for this research, which seeks to generate insight into the potential spillover effects of ABS.

\section{Framework and Hypotheses}

Figure 1 gives an overview of our research framework, which is deduced in the following section, and depicts how the unintended trials within ABS impact customers' attitudes, purchase intentions, and WOM, whereas these effects are moderated by the valence, i.e., customers' evaluations of their trial experience and involvement. 


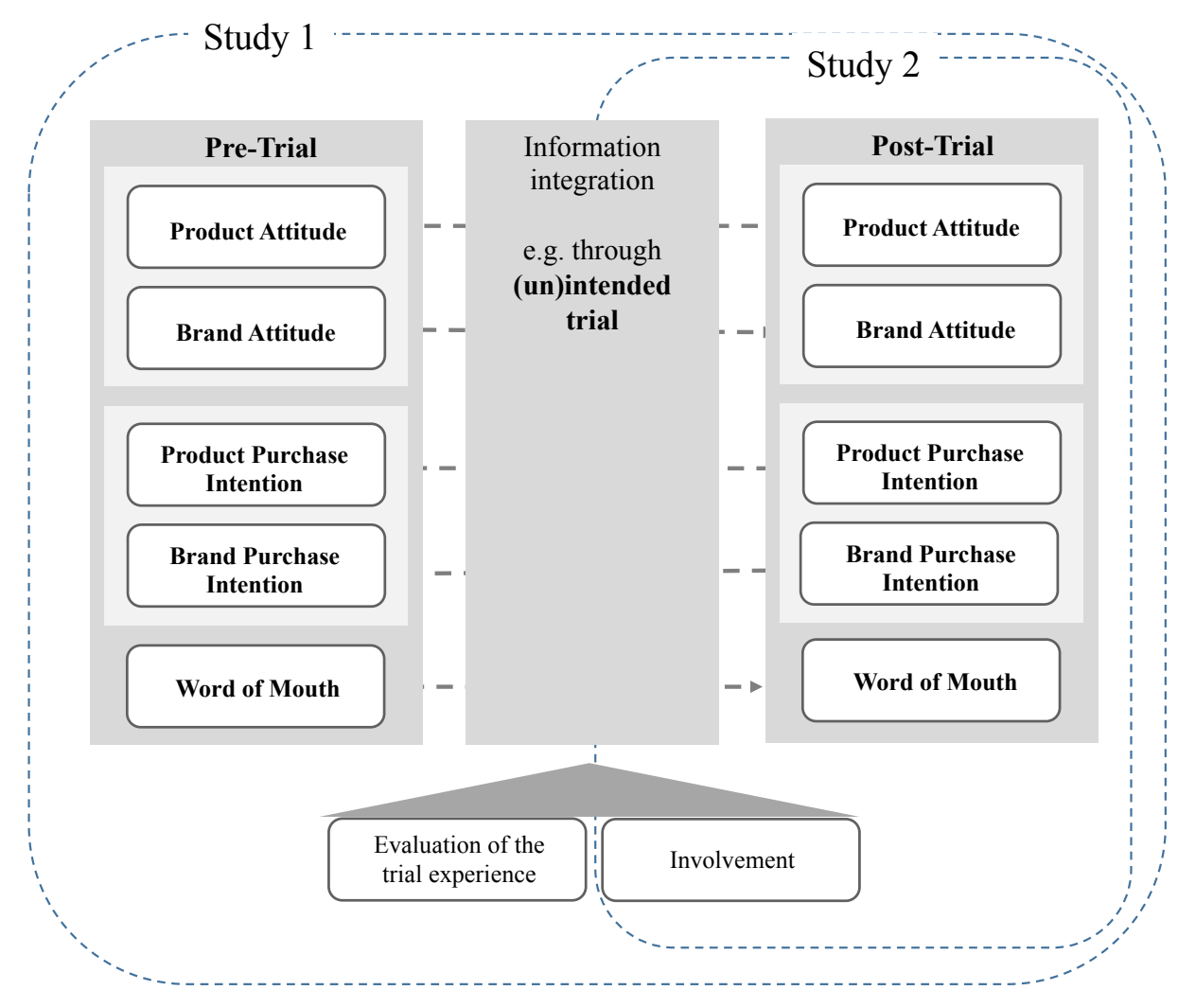

\section{Figure 1: Conceptual framework}

\section{Spillover effects from unintended trials during ABS}

According to Kim and Morris (2007) and Kempf (1999), positive trial experiences enhance product attitudes. This is in line with the findings of Smith (1993), who postulates that information has high credibility if it is self-generated, i.e., resulting from one's own experience. In line with IIT and the previous literature showing the effects of ABS on product and parent brand perception (Baumeister et al., 2015), we differentiated between attitudes toward products (e.g., an e-car) and brands (e.g., a BMW). In addition to attitude, IIT also assumes an effect from information integration on decision making, and hence we included three variables representing behavioral intention. We included purchase intention in our study since it is a variable with high managerial relevance, again, differentiated according to whether it relates to the product or the brand. In addition, WOM was integrated into the study to enable the detection of smaller-scale behavioral effects, i.e., spreading of opinion. WOM has also proven to be a highly relevant variable for the purchase behavior of others (Iyengar 
et al., 2015). In line with our definition, trials happen when individuals are exposed to and experience largely unknown products. As a result, trial information and its spillover effects can be especially important for innovative products that evoke greater uncertainty and risk, which are critical aspects in new product adoption (Ma, Gill, \& Jiang, 2015).

A trial experience that is naturally personal increases consumers' processing of product-related information and understanding of functionality, which, in the event of a positive experience, usually has positive effects on product attitudes (Mooy \& Robben, 2002). In the current research context, consumers experience the performance and usability of a largely unknown product, e.g., e-cars, through an unintended trial using ABS. Because positive evaluations (valence) of a trial experience (information) represent the valence of product-related information in IIT, we argue that a positive (as opposed to e.g. a neutral) experience should improve the overall response and enhance the impact of the trial on consumer attitudes (Grace \& O'Cass, 2004; Suh \& Youjae, 2006). Beyond positive spillover effects on attitude, we argue that the same holds for consumer behavior. When consumers gain a better understanding of a new product during a positive trial experience and learn about its usability and performance, the information gathered will have a positive effect and they will consequently express stronger intentions to buy the product in the future.

Moreover, information integration (Anderson, 1991) and the adoption of new products are often accompanied by increased communication (Wien \& Olsen, 2014). WOM, defined as "information about products, services, stores, companies ... spread from one consumer to another" (Brown, Barry, Dacin, \& Gunst, 2005, p. 125), has a significant impact on consumer attitudes and behavior, leading from increased awareness of trials to purchase decisions (Berger, 2014; Packard \& Berger, 2017). It can be triggered by product experience, such as through intended or unintended trials, since it conveys diagnostic information from one consumer to another (Gershoff, Mukherjee, \& Mukhopadhyay, 2003). In fact, previous 
research suggests a high relevance of social influence in product trials (Iyengar et al., 2015). In line with current research on how WOM spreads after product- and brand-related experiences (Chen \& Lurie, 2013; De Angelis, Bonezzi, Peluso, Rucker, \& Costabile, 2012; Leisen Pollack, 2017; Packard \& Berger, 2017; Triantafillidou \& Siomkos, 2014), this study restricts its analysis to positive WOM intentions and focuses on a positive trial experience with the product through ABS, which should amplify the change in consumers' intentions to spread positive WOM about the new product (in this case, e-cars) (Krishen \& Hu, 2018).

H1. Trial experiences (from unintended product trials during ABS) impact (a) product attitude, (b) brand attitude, (c) product purchase intention, (d) brand purchase intention, and (e) WOM.

H2. The effect of an unintended trial during ABS on (a) product attitude, (b) brand attitude, (c) product purchase intention, (d) brand purchase intention and (e) WOM is positively strengthened in cases of a favorable trial experience.

Unlike intended trials, which imply that the consumer has an evaluative mindset (Kempf, 1999), unintended trials during ABS occur incidentally. Nevertheless, they should still be considered as trials since they are undertaken by the consumer and are accordingly interactive, self-generated, and multi-sensual, in contrast to alternative sources of information such as traditional advertising (Kempf \& Smith, 1998; Kempf, 1999; Smith \& Swinyard, 1983). We therefore chose the term "unintended trial" to refer to such trials. Moreover, trialbased information from personal exposure to a product rather than from a report of someone else's experience is usually higher in relevance and trustworthiness. In IIT terminology, such information has more weight (Smith, 1993). We thus propose a stronger spillover effect of an (un)intended trial compared to non-trial information on attitude and behavioral intentions.

H3. The effect of a favorable (un)intended trial on (a) product attitude, (b) brand attitude, (c) product purchase intention, (d) brand purchase intention and (e) WOM is stronger than the effect of non-trial information.

We hypothesize a positive impact of both types of trials on consumers' attitudes and behavioral intentions. However, because unintended trials happen incidentally, they might only involve peripheral perception and hence information integration. As argued by Kempf 
(1999), during (intended) trials, consumers are in an evaluative mindset. By extension, we can say that when exposed to a product during ABS (what we termed unintended trials), consumers are not in such a mindset. This mindset might thus make a difference to information integration as well as to attitude formation and behavioral intentions. We therefore propose that intended trials show larger effects on attitude and behavioral intentions than unintended ones.

H4. The effect of a favorable intended trial on (a) product attitude, (b) brand attitude, (c) product purchase intention, (d) brand purchase intention, and (e) WOM is stronger than the effect of favorable unintended trials.

Involvement is "a person's perceived relevance of the object based on inherent needs, values, and interests" (Zaichkowsky, 1985, p. 342). According to IIT, this form of importance of an item of information — or weight — is central to attitude formation (Anderson, 1971, 1981). Prior research has identified the influence of product category involvement on information search, attitude formation, purchase decisions, and generation of WOM (Lin \& Chen, 2006; Mazodier \& Merunka, 2014; Priluck \& Till, 2004; Wangenheim \& Bayón, 2007). Particularly such enduring involvement with a product is a stable trait and impacts the attention to product-related messages and behavioral outcomes (Richins and Bloch, 1996). In compliance with the diagnosticity and necessary efforts associated with trials, research on trials also indicates that attitude formation differs depending on consumers' involvement with the product (Kim \& Morris, 2007). In line with IIT, involvement should provide a good proxy of how important the information for consumers is and hence its influence on attitude formation and behavioral intention.

Going beyond the situational evaluative consumer mindset of a trial, highly involved consumers permanently seek more product-related information and pay more attention to information about product attributes (Celsi \& Olson, 1988; Dholakia, 2001; Lin \& Chen, 2006). These consumers also seem more prone to discovering new products. We also assume that consumers with high product involvement gather and integrate more information even if 
they are exposed to the product concomitantly rather than with a concrete trial purpose. The users of ABS who are more involved in the category of the underlying product (i.e., e-cars) should thus be more prone to process the information they obtain compared to consumers with low involvement. In turn, ABS customers marked by high involvement may be more affected by the usage, and therefore, the resulting attitudinal and behavioral changes might be more pronounced.

Furthermore, involvement may also be relevant for affecting changes in people's intentions to spread WOM after their ABS usage (H5(c)). Previous research has established that highly involved consumers tend to spread information to others (Dholakia, 2001; Richins \& Bloch, 1986; Wangenheim \& Bayón, 2007). Accordingly, consumers who are highly involved with the product they use in ABS are more likely-compared with less involved consumers - to spread positive WOM after their trial experience.

H5. Product involvement strengthens the effect of a favorable unintended as opposed to a favorable intended trial on (a) product attitude, (b) product purchase intention and (c) product-related WOM.

\section{Empirical Studies}

To test our hypotheses, we conducted two studies. Study 1 was a field study investigating the effects of an unintended trial on attitude and behavioral intention, additionally testing the moderation effects. Study 2 was an online experiment comparing and contrasting non-trial situations, unintended trials, and intended trials. Prompted by interesting results from Study 1, in Study 2 we also further investigated the role of involvement in information integration.

\section{Set-up, Study 1}

The field study was conducted in cooperation with an independent ABS (car sharing) provider in Germany. It allows registered customers to access a fleet of both combustionengine and e-cars for short-term usage in return for a per-minute and per-kilometer fee. This 
service provider recently introduced e-cars to its customers. The data collection spanned the periods before and after the introduction of the new product.

\section{Procedure and sample, Study 1}

The service provider we partnered with invited customers who had not yet used the ecars available through the ABS to participate. The description of the research design explained that participants would complete a pre-usage survey, use the new e-car, and then complete a post-usage survey. To incentivize the use of the new product and participation in this study, each respondent earned free kilometers by completing all of the steps in the research process. A sample of 265 respondents completed the pre-usage survey, of whom 76 used an e-car via the ABS. These consumers received another email inviting them to complete the post-usage survey, and 61 participants between the ages of 19 and 75 years (26\% women) completed all three steps.

\section{Measures, Study 1}

The questionnaires contained well-established scales adapted to the research context (see Appendix A). In both the pre- and post-surveys, respondents answered questions about their attitudes, purchase, and WOM, in relation to e-cars. The measures were thus adapted to the empirical context to make answering easier and more concrete for the respondents.

Attitudes and purchase intention also referred to the specific car brand available for the field study. The scale types were varied to reduce the likelihood of common method bias (S.-J. Chang, Van Witteloostuijn, \& Eden, 2010; Podsakoff, MacKenzie, Lee, \& Podsakoff, 2003). In both the pre- and post-usage surveys, participants indicated their attitudes toward e-cars on a multi-item, seven-point, semantic differential scale (adapted from Bergkvist \& Rossiter, 2007; Tybout, Sternthal, Malaviya, Bakamitsos, \& Park, 2005). The brand attitude measure used a five-point, semantic differential scale (adapted from Bergkvist \& Rossiter, 2007). Ecar purchase intentions were measured on a seven-point Likert scale, and brand purchase 
intentions were evaluated on a five-point Likert scale (both adapted from Dodds, Monroe, \& Grewal, 1991). Furthermore, WOM was measured on a five-point Likert scale (adapted from Maxham III, 2001).

In the pre-usage survey, participants also completed an involvement scale to evaluate their general interest in the underlying product (in our case, e-cars). The adapted items, measured on a five-point Likert scale, came from Beatty and Talpade (1994) as well as from Ghosh (2016). After using the car through the ABS, participants evaluated their overall trial experience with the ABS on an adapted, five-point, semantic differential scale based on Kempf (1999).

All of the measures were highly reliable, with Cronbach's $\alpha$ values of between .82 and .92 (see Appendix A), thus allowing the scale averages to be used in the analysis. Because the key variables measured occurred both pre- and post-usage, difference scores (post-usage minus pre-usage scores) were calculated to capture changes. Table 1 provides a detailed overview of the descriptive results, including the positive and negative changes in the observed variables on individual levels, as well the positive overall average effect. 
Table 1: Literature overview

\begin{tabular}{|c|c|c|c|}
\hline Focus & Topic & Existing research & Research Approach \\
\hline \multicolumn{4}{|c|}{ Trial Research } \\
\hline \multirow[t]{4}{*}{$\begin{array}{l}\text { Intended } \\
\text { Trials }\end{array}$} & $\begin{array}{l}\text { Impact of trial compared to advertising information on consumer } \\
\text { responses (e.g., attitude formation, behavior) }\end{array}$ & $\begin{array}{l}\text { Hamilton and Thompson (2007); Kempf and Smith } \\
\text { (1998); Smith and Swinyard (1983) }\end{array}$ & \multirow[t]{4}{*}{$\begin{array}{l}\text { Lab experiment(s), } \\
\text { quantitative/empirical }\end{array}$} \\
\hline & $\begin{array}{l}\text { Impact of hedonic and functional product trials on consumers' affective } \\
\text { and cognitive responses (pleasure, arousal, brand cognition) }\end{array}$ & $\operatorname{Kempf}(1999)$ & \\
\hline & $\begin{array}{l}\text { Impact of advertising, pre-trial and trial information on attitude formation } \\
\text { and consumer behavior }\end{array}$ & Kempf and Laczniak (2001) & \\
\hline & $\begin{array}{l}\text { Impact of information source (direct, indirect, virtual) of trial and } \\
\text { advertising information on consumer attitudes and behavior }\end{array}$ & Daugherty, Lin, and Biocca (2008) & \\
\hline $\begin{array}{l}\text { Unintended } \\
\text { Trials }\end{array}$ & $\begin{array}{l}\text { Definition and differentiation of the concept "unintended trial" and its } \\
\text { effects towards intended trials }\end{array}$ & This study & $\begin{array}{l}\text { Pre- and post-usage, field study, lab } \\
\text { experiment, quantitative/empirical }\end{array}$ \\
\hline \multicolumn{4}{|c|}{ Trial in Information Integration Theory (IIT) Research } \\
\hline \multirow[t]{4}{*}{$\begin{array}{l}\text { Intended } \\
\text { Trials in IIT }\end{array}$} & $\begin{array}{l}\text { Impact and interplay of advertising and product trial information in } \\
\text { different settings (e.g., gender, product knowledge, pre-trial/ post-trial } \\
\text { ad) }\end{array}$ & $\begin{array}{l}\text { Chang (2004); Kempf, Laczniak, and Smith (2006); } \\
\text { Micu and Coulter (2012); Smith (1993) }\end{array}$ & \multirow[t]{4}{*}{ Experimental, quantitative/empirical } \\
\hline & $\begin{array}{l}\text { Impact of affective responses to, and cognitive structures in, product trial } \\
\text { attitude formation }\end{array}$ & Kim and Morris (2007) & \\
\hline & $\begin{array}{l}\text { Impact of direct and virtual product trials, as well as conscious and } \\
\text { unconscious arousal, on attitude formation }\end{array}$ & Bettiga et al. (2017) & \\
\hline & $\begin{array}{l}\text { Impact of different service trial offers (varying pricing, delivery method, } \\
\text { type of product) on trial acceptance and likelihood of purchase }\end{array}$ & Bednall et al.(2018) & \\
\hline $\begin{array}{l}\text { Unintended } \\
\text { trials in IIT }\end{array}$ & $\begin{array}{l}\text { Impact of unintended trials on attitude formation and subsequent } \\
\text { consumer behavior in a service setting, as well as the impact of } \\
\text { amplifying variables }\end{array}$ & This study & $\begin{array}{l}\text { Pre- and post-usage, field study, online } \\
\text { experiment, quantitative/empirical }\end{array}$ \\
\hline \multicolumn{4}{|c|}{ Access-Based Consumption } \\
\hline $\begin{array}{l}\text { Consumer } \\
\text { perspective }\end{array}$ & $\begin{array}{l}\text { Drivers of and barriers to access-based consumption, such as (flexibility) } \\
\text { utility, convenience, cost, trends, materialism, familiarity, emerging } \\
\text { adulthood life stage, and functional and psychological barriers }\end{array}$ & $\begin{array}{l}\text { Akbar, Mai, and Hoffmann (2016); Bardhi and } \\
\text { Eckhardt (2012); Davidson, Habibi, and Laroche } \\
\text { (2018) Hazée et al. (2017); Hazée et al. (2019); } \\
\text { Lamberton and Rose (2012); Lawson et al. (2016); } \\
\text { Moeller and Wittkowski (2010); Oyedele and } \\
\text { Simpson (2018) }\end{array}$ & $\begin{array}{l}\text { Quantitative and qualitative, empirical, } \\
\text { cross-sectional, survey data }\end{array}$ \\
\hline \multirow[t]{3}{*}{$\begin{array}{l}\text { Brand } \\
\text { perspective }\end{array}$} & $\begin{array}{l}\text { Impact of an announcement of new ABS on brand attitudes and } \\
\text { perceived innovativeness of the brand }\end{array}$ & Baumeister et al. (2015) & $\begin{array}{l}\text { Experimental, quantitative, empirical, } \\
\text { cross-sectional, survey data }\end{array}$ \\
\hline & $\begin{array}{l}\text { Impact of the "burdens of ownership" on the use of ABS and the } \\
\text { reduction of ownership }\end{array}$ & Schaefers, Lawson et al. (2016) & $\begin{array}{l}\text { Quantitative, empirical, cross- } \\
\text { sectional, survey data }\end{array}$ \\
\hline & $\begin{array}{l}\text { Positive spillover effects caused by ABS usage and identification of its } \\
\text { amplifiers }\end{array}$ & This study & $\begin{array}{l}\text { Pre- and post-usage, field study, lab } \\
\text { experiment, quantitative/empirical }\end{array}$ \\
\hline
\end{tabular}




\section{Analysis, Study 1}

Our dependent variables were pre- and post-trial difference scores for product and brand attitude, product and brand purchase intentions, and WOM. Before creating them, we ran a paired sample t-test, providing insights into the pre- and post-usage effects. The hypothesis tests relied on several multiple regressions. The predictors of the difference scores were customers' perceived trial experience and product involvement. This method matches current approaches in the literature for these kinds of studies with more than one data collection point (He, Chen, \& Alden, 2016).

\section{Results, Study 1}

A comparison of pre- and post-usage scores provides insights into the main effects of unintended trials (see Table 3). All but one of the outcome variables used in this research show an increase, implying positive spillover effects from ABS. In more detail, the unintended trial increased product attitude $\left(\mathrm{M}_{\text {product_pre }}=5.96, \mathrm{M}_{\text {product-post }}=6.29 ; \mathrm{t}(60)=-\right.$ $2.917, p=.005)$, brand attitude $\left(\mathrm{M}_{\text {brand-pre }}=5.11, \mathrm{M}_{\text {brand-post }}=5.52 ; \mathrm{t}(60)=-3.75, p<.001\right)$, brand purchase intention $\left(\mathrm{M}_{\text {pi-brand-pre }}=2.61, \mathrm{M}_{\text {pi-brand-post }}=2.86 ; \mathrm{t}(60)=-2.64, p=.01\right)$, and WOM $\left(\mathrm{M}_{\text {wom-pre }}=3.93, \mathrm{M}_{\text {wom-post }}=4.20 ; \mathrm{t}(60)=-3.14, p=.003\right)$, supporting H1(a), H1(b), H1(d), and H1(e). However, the results did not indicate any significant increase in product purchase intentions, in our case the e-car $\left(\mathrm{M}_{\text {product-pi-pre }}=4.06, \mathrm{M}_{\text {product-pi-post }}=4.17 ; \mathrm{t}(60)=-\right.$ $.65, p<.52)$, and thus H1(c) is not supported.

Examining the hypothesized moderation effects of the valence of the trial experience, two out of the five outcome variables were strengthened by it. In support of $\mathrm{H} 2(\mathrm{a})$ and $\mathrm{H} 2(\mathrm{e})$, a positive trial experience significantly strengthened the change in product attitude $(\beta=.42, p$ $=.002)$ and WOM $(\beta=.43, p=.001)$. However, it did not strengthen the change in brand attitude $(\mathrm{H} 2(\mathrm{~b}), \beta=.21, p=.11)$, the product purchase intention $(\mathrm{H} 2(\mathrm{c}), \beta=.16, p=.27)$, or the brand purchase intention ( $\mathrm{H} 2(\mathrm{~d}), \beta=.07, p=.62)$. 
In line with the literature, we also hypothesized a strengthening effect of product involvement on the trial-related change in product attitude and behavioral intentions $(\mathrm{H} 5(\mathrm{a}-\mathrm{c}))$. However, we found the opposite effect, revealing that involvement weakens the positive change in product attitude (H5(a), $\beta=-.38, p=.004)$ and WOM (H5(c): $\beta=-.39, p=.003)$. Furthermore, involvement had no effect on changes in product purchase intention (H5(b), $\beta=-.03, p=.82)$. Our results thus suggest that consumers who are highly involved appear less influenced by the unintended trial. Table 2 provides a detailed overview of the results, which will be discussed in more detail later.

The relatively small sample size of this field study (He et al., 2016) might create concerns; therefore, Cohen's f2 ( $\geq .20)$ serves to capture the effect sizes of the multiple regressions, and $G^{*}$ Power provides a test of the statistical power $(\geq .87)$. All of the results reached the required thresholds (Cohen, 1988; Faul, Erdfelder, Buchner, \& Lang, 2009). In addition, a bootstrapping procedure tests the robustness of the regressions. It is a common approach in marketing research to gauge the sensitivity of estimates in smaller sample sizes (e.g. Morgeson III, Mithas, Keiningham, \& Aksoy, 2011; Xu, Forman, Kim, \& Van Ittersum, 2014). The results of these bootstrap estimations with 10,000 resamples support the main findings and confirm the significant results for the supported hypotheses: $H 2(a)(\beta=.42$; bootstrapped $\mathrm{SE}=.161, \mathrm{p}=.03), \mathrm{H} 2(\mathrm{e})(\beta=-.39 ;$ bootstrapped $\mathrm{SE}=.072, p=.002) ; \mathrm{H} 5(\mathrm{a})$ $(\beta=-.38 ;$ bootstrapped SE $=.118, \mathrm{p}=.011), \mathrm{H} 5(\mathrm{c})(\beta=.43 ;$ bootstrapped $\mathrm{SE}=.099$, $p=.001)$. Because of the small sample size, we also refrained from using control variables in our final analysis. In line with the literature, we included the control variables in the initial analysis, but because they did not have a significant effect, we excluded them so as not to weaken the statistical power (Cui \& O’Connor, 2012). 
Table 2: Descriptive results of Study 1 and Study 2

\begin{tabular}{|c|c|c|c|c|c|c|c|}
\hline \multicolumn{8}{|c|}{ Study $1, n=61$, Within-subject design } \\
\hline & \multicolumn{5}{|c|}{ Deltas of Dependent Variables } & \multicolumn{2}{|c|}{$\begin{array}{c}\text { Independent (Moderator) } \\
\text { Variables } \\
\end{array}$} \\
\hline & $\begin{array}{l}\text { Product } \\
\text { Attitude }\end{array}$ & $\begin{array}{c}\text { Brand } \\
\text { Attitude }\end{array}$ & $\begin{array}{c}\text { Product } \\
\text { Purchase } \\
\text { Intention }\end{array}$ & $\begin{array}{c}\text { Brand } \\
\text { Purchase } \\
\text { Intention }\end{array}$ & WOM & $\begin{array}{c}\text { Trial } \\
\text { Experience }\end{array}$ & $\begin{array}{c}\text { Product } \\
\text { Involvement }\end{array}$ \\
\hline Mean & .321 & .413 & .115 & .250 & .262 & 4.463 & 3.602 \\
\hline $\begin{array}{l}\text { Standard } \\
\text { deviation }\end{array}$ & .860 & .860 & 1.390 & .739 & .653 & .825 & 1.031 \\
\hline Variance & .740 & .740 & 1.932 & .546 & .426 & .681 & 1.063 \\
\hline Minimum & -1.80 & -1.40 & -3.75 & -1.00 & -2.00 & 1.00 & 1.00 \\
\hline Maximum & 2.40 & 3.20 & 3.50 & 3.00 & 1.75 & 5.00 & 5.00 \\
\hline \multicolumn{8}{|c|}{ Study 2, n=147, Between-subject design } \\
\hline & \multicolumn{5}{|c|}{ Dependent Variables (Totals) } & \multicolumn{2}{|c|}{ Moderator Variables } \\
\hline & $\begin{array}{l}\text { Product } \\
\text { Attitude }\end{array}$ & $\begin{array}{c}\text { Brand } \\
\text { Attitude }\end{array}$ & $\begin{array}{c}\text { Product } \\
\text { Purchase } \\
\text { Intention }\end{array}$ & $\begin{array}{c}\text { Brand } \\
\text { Purchase } \\
\text { Intention }\end{array}$ & WOM & \multicolumn{2}{|c|}{ Product Involvement } \\
\hline Mean & 6.11 & 5.83 & 4.34 & 4.45 & 4.51 & \multicolumn{2}{|c|}{3.66} \\
\hline $\begin{array}{l}\text { Standard } \\
\text { deviation }\end{array}$ & 1.03 & .97 & 1.41 & 1.20 & 1.57 & \multicolumn{2}{|c|}{1.66} \\
\hline Variance & 1.07 & .94 & 2.00 & 1.46 & 2.49 & \multicolumn{2}{|c|}{2.783} \\
\hline Minimum & 1.20 & 1.00 & 3.00 & 1.00 & 1.00 & \multicolumn{2}{|c|}{1.00} \\
\hline Maximum & 7.00 & 7.00 & 7.00 & 7.00 & 7.00 & \multicolumn{2}{|c|}{7.00} \\
\hline
\end{tabular}

The check for potential structural differences between respondents who only answered the pre-usage survey and those who completed all three steps relied on several post hoc analyses of variance. Checks of whether respondents who completed the study were more engaged in the topic of e-cars or more eco-conscious did not reveal any significant group differences for the focal variables: involvement, environmental consciousness, noveltyseeking, or brand attitude (all $p>.05$ ).

Overall, and in partial support of IIT, this study reveals positive spillover effects from ABS usage for brands of products available through ABS - mainly on attitude and WOM, and particularly among customers who do not indicate high involvement. 


\section{Set-up, Study 2}

Study 2, an online experiment, had two main purposes. Firstly, to further corroborate the positive spillover effects from the field study, we compared and contrasted non-trial information integration with trial information, particularly contrasting the positive effect of intended and unintended trials. Prompted by the interesting results from Study 1, we further investigated the role of involvement in information integration. We did so to balance the high external validity of the field study with high internal validity from a more controlled environment (Malhotra \& Birks, 2007). Secondly, we further investigated the role of involvement in the effect of unintended trials that showed a non-hypothesized negative effect in the field study.

\section{Procedure and sample, Study 2}

To collect data for Study 2, we used an online panel hosted by an international market research firm that provided a small monetary incentive for participation. The participants were UK citizens. We implemented a number of steps to ensure valid data. First, for the manipulations, we used text and graphics to support the cognitive processing of the manipulation, such as previous studies in car sharing (Schaefers, Wittkowski, Benoit, \& Ferraro, 2016). Secondly, we included manipulation and attention checks and discontinued the participation of those respondents who failed the attention checks. The latter differ from manipulation checks in that they capture correct reading or memory rather than perception (Lonati, Quiroga, Zehnder, \& Antonakis, 2018). Thirdly, we measured overall response times and excluded two respondents who completed the survey too quickly, in under 2 minutes when the median response time was 4 minutes and 12 seconds. Furthermore, due to our focus on consumers' information integration for relatively new products, we eliminated one participant who stated he had an e-car in his household. The final sample included 147 
participants distributed randomly across the experimental conditions. The participants were between the ages of 18 and 74 years, with a mean age of 39.9 , and $69.4 \%$ were female.

\section{Manipulations and measures, Study 2}

Study 2 employed the same measures and different scale types similar to Study 1, again to reduce the likelihood of common method bias. The items as well as the manipulation and attention checks are displayed in Appendix A. The vignettes used for the experimental manipulation are displayed in Appendix B. The intended trial was operationalized as a consumer deliberately booking a test drive of an e-car at a nearby car dealer. The unintended trial was operationalized as having incidentally driven an e-car using a car-sharing program (see Appendix B). We included a non-trial control group who read in a leaflet about someone else's favorable experience of driving this vehicle. Our experimental design was created to reduce biases. Firstly, in line with previous marketing research and following common practice, in Study 2 we used a fictitious brand so as not to risk confounding factors due to prior brand associations (Keller \& Aaker, 1992). Secondly, to avoid demand effects, meaning that participants receive cues "about what constitutes appropriate behavior" (Zizzo, 2010), we refrained from adopting pre- and post- designs similar to the field study as it would have entailed asking for attitude, purchase intention, and WOM twice within a short period of time: once before the manipulation and once afterward. We therefore used a between-subject design with three conditions and random sampling, allowing us to compare the effects of the manipulations on the outcome variables. 
Table 3: Results of Study 1 and 2

\begin{tabular}{|c|c|c|c|c|c|c|c|c|c|}
\hline \multicolumn{10}{|l|}{ Study 1} \\
\hline $\begin{array}{l}\text { Independent } \\
\text { Variable }\end{array}$ & Dependent Variable (DV) & & & & Mpre & Mpost & $t$ & $p$ & \\
\hline \multirow{5}{*}{$\begin{array}{l}\text { Unintended } \\
\text { trial }\end{array}$} & \multirow{5}{*}{$\begin{array}{l}\text { H1(a): Product Attitude } \\
\text { H1(b): Brand Attitude } \\
\text { H1(c): Product Purchase Intention } \\
\text { H1(d): Brand Purchase Intention } \\
\text { H1(e): WOM }\end{array}$} & & & & 5.96 & 6.29 & -2.917 & .005 & sig. \\
\hline & & & & & 5.11 & 5.52 & -3.75 & .001 & sig. \\
\hline & & & & & 4.06 & 4.17 & -.65 & .52 & n.s. \\
\hline & & & & & 2.61 & 2.86 & -2.64 & .01 & sig. \\
\hline & & & & & 3.93 & 4.20 & -3.14 & .003 & sig. \\
\hline $\begin{array}{l}\text { Independent } \\
\text { Variable } \\
\end{array}$ & Dependent Variable (DV) & $\begin{array}{c}\text { Adj. } \\
\mathbf{R}^{2} \\
\end{array}$ & $\mathbf{F}$ & sig. & $\boldsymbol{\beta}$ & $\mathbf{t}$ & $p$ & Нурс & hesis \\
\hline \multirow{5}{*}{$\begin{array}{l}\text { Trial } \\
\text { experience } \\
\text { (perceived) }\end{array}$} & \multirow{5}{*}{$\begin{array}{l}\text { H2(a): Product Attitude } \\
\text { H2(b): Brand Attitude } \\
\text { H2(c): Product Purchase Intention } \\
\text { H2(d): Brand Purchase Intention } \\
\text { H4(a): WOM }\end{array}$} & .17 & 7.38 & .002 & .42 & 3.30 & .002 & $\mathrm{H} 2 \mathrm{a}$ & sig. \\
\hline & & .03 & 2.62 & .111 & .21 & 1.62 & .11 & $\mathrm{H} 2 \mathrm{~b}$ & n.s. \\
\hline & & -.01 & 0.65 & .528 & .16 & 1.12 & .27 & $\mathrm{H} 2 \mathrm{c}$ & n.s. \\
\hline & & -.01 & .25 & .619 & .07 & .50 & .62 & $\mathrm{H} 2 \mathrm{~d}$ & n.s. \\
\hline & & .18 & 7.59 & .001 & .43 & 3.39 & .001 & $\mathrm{H} 4 \mathrm{a}$ & sig. \\
\hline \multirow[t]{3}{*}{ Involvement } & \multirow{3}{*}{$\begin{array}{l}\text { H5(a): Product Attitude } \\
\text { H5(b): Product Purchase Intention } \\
\text { H5(c): WOM }\end{array}$} & .17 & 7.38 & .002 & -.38 & -2.96 & .004 & $\mathrm{H} 6 \mathrm{a}$ & r.e. \\
\hline & & -.01 & 0.65 & .528 & -.03 & -0.23 & .82 & $\mathrm{H} 6 \mathrm{~b}$ & n.s. \\
\hline & & .18 & 7.59 & .001 & -.39 & -3.06 & .003 & H6c & r.e. \\
\hline \multicolumn{10}{|l|}{ Study 2} \\
\hline $\begin{array}{l}\text { Independent } \\
\text { Variables } \\
\end{array}$ & Dependent Variable (DV) & \multicolumn{2}{|c|}{$M_{\text {non-trial }}$} & \multicolumn{2}{|c|}{$\mathbf{M}_{\text {intended }}$} & \multicolumn{2}{|c|}{ Munintended } & $p$ & \\
\hline \multirow{5}{*}{$\begin{array}{l}\text { Intended, } \\
\text { unintended } \\
\text { trial vs non- } \\
\text { trial } \\
\text { (ANCOVA) } \\
\end{array}$} & \multirow{5}{*}{$\begin{array}{l}\text { H1(a): Product Attitude } \\
\text { H1(b): Brand Attitude } \\
\text { H1(c): Product Purchase Intention } \\
\text { H1(d): Brand Purchase Intention } \\
\text { H1(e): WOM }\end{array}$} & \multicolumn{2}{|c|}{5.80} & \multicolumn{2}{|c|}{6.22} & \multicolumn{2}{|c|}{6.33} & .034 & sig. \\
\hline & & \multicolumn{2}{|c|}{5.55} & \multicolumn{2}{|c|}{5.86} & \multicolumn{2}{|c|}{6.13} & .004 & sig. \\
\hline & & \multicolumn{2}{|c|}{4.37} & \multicolumn{2}{|c|}{4.09} & & 57 & .230 & n.s. \\
\hline & & & & & & & 82 & .026 & sig. \\
\hline & & & & & & & 76 & .302 & n.s. \\
\hline Trials $v s$ & & & & & & & & .166 & n.s. \\
\hline Non-trial & H3(a): Product Attitude & & & & & & & .038 & sig. \\
\hline (pairwise & & & & & & & & .225 & n.s. \\
\hline comparison) & H3(b): Brand Attitude & & & & & & & .003 & sig. \\
\hline & & & & & & & & 1.00 & n.s. \\
\hline & (c): Product Purchase Intention & & & & & & 57 & .816 & n.s. \\
\hline & H3(d) · Rrand Purchase Intention & & & & & & & 1.00 & n.s. \\
\hline & H3(a): Brand Purchase intention & & & & & & 82 & .071 & n.s. \\
\hline & & & & & & & & 1.00 & n.s. \\
\hline & H3(e & & & & & & & .438 & n.s. \\
\hline Intended $v s$ & H4(a): Product Attitude & & & & & & 33 & 1.00 & n.s. \\
\hline unintended & H4(b): Brand Attitude & & & & & & 13 & .319 & n.s. \\
\hline trial (pairwise & H4(c): Product Purchase Intention & & & & & & 57 & .276 & n.s. \\
\hline comparison) & H4(d): Brand Purchase Intention & & & & & & 82 & .049 & sig. \\
\hline & H4(e): WOM & & & & & & 76 & .719 & n.s. \\
\hline $\begin{array}{l}\text { Independent } \\
\text { Variables } \\
\end{array}$ & Dependent Variable (DV) & $\begin{array}{c}\text { Adj. } \\
\mathbf{R}^{2} \\
\end{array}$ & $\mathbf{F}$ & sig. & $\boldsymbol{\beta}$ & $\mathbf{t}$ & $p$ & & \\
\hline $\begin{array}{l}\text { Intended } v s \\
\text { unintended }\end{array}$ & H5(a): Product Attitude & .15 & 2.69 & .291 & .086 & .834 & $\begin{array}{r}.115( \\
.11 \mathrm{t} \\
\end{array}$ & $\begin{array}{l}95 \%- \\
.29) \\
\end{array}$ & n.s. \\
\hline $\begin{array}{l}\text { trial X } \\
\text { involvement }\end{array}$ & H5(b): Product Purchase Intention & .62 & 25.46 & .279 & .053 & .466 & $\begin{array}{r}.642( \\
.17 \mathrm{t} \\
\end{array}$ & $\begin{array}{l}\text { I95\%- } \\
.27) \\
\end{array}$ & n.s. \\
\hline & H5(c): WOM & .67 & 30.84 & .331 & .093 & .779 & $\begin{array}{r}.437( \\
.14 \mathrm{t}\end{array}$ & $\begin{array}{l}95 \%- \\
.33)\end{array}$ & n.s. \\
\hline
\end{tabular}

Notes: sig. = significant effect or confirmed hypothesis; r.e. = reversed effect, i.e. significant coefficient contradicting hypothesis; n.s. = nonsignificant coefficient. ANCOVAs and regressions in Study 2 were performed with three control variables, i.e. gender, age and familiarity left out for parsimony of the result presentation; moderation analyses were based on 5,000 bootstrap resamples using Hayes' PROCESS model 4 


\section{Results, Study 2}

To test H1(a-e) (main effects), we ran ANCOVAs with our five dependent variables as used in Study 1; type of trial as an independent variable; and gender, age, and familiarity with e-cars as covariates (see Table 3). To test the differential effects of information from nontrials versus trials (H3) and intended versus unintended trials (H4), we used Bonferroniadjusted post hoc tests to not only correct for the influence of the covariates but also to pairwise compare the experimental groups.

Examining product and brand attitude first, in line with $\mathrm{H1}(\mathrm{a}, \mathrm{b})$, we found a significant main effect of the manipulation (Product attitude: $\mathrm{M}_{\text {non-trial }}=5.80, \mathrm{M}_{\text {intended }}=6.22 ; \mathrm{M}_{\text {unintended }}$ $=6.33, \mathrm{~F}(2,140)=3.47, p=.034 ;$ Brand attitude: $\mathrm{M}_{\text {non-trial }}=5.55, \mathrm{M}_{\text {intended }}=5.86 ; \mathrm{M}_{\text {unintended }}$ $=6.13, \mathrm{~F}(2,140)=5.814, p=.004)$. In line with $\mathrm{H} 3(\mathrm{a})$, the results show a significantly stronger positive effect of the information gathered during an unintended trial on product attitude than of the non-trial information, but interestingly, and in contrast to H4(a), there was no significant difference in product attitude between the two types of trials (Product attitude: $\mathrm{M}_{\text {intended-non-trial }}=.397, p=.166, \mathrm{M}_{\text {unintended-non-trial }}=.518, p=.038, \mathrm{M}_{\text {intended-unintended }}=-.12$, $p=1.0$ ). For brand attitude, we found a significantly stronger effect of unintended trial than of non-trial (in support of H3(b)), but again no difference between the two types of trials, nor the intended trial and the non-trial, which is again in contrast to $H 4(b$,$) but in line with the$ previous results relating to product attitude $(\mathrm{H} 4(\mathrm{a}))$ (Brand attitude: $\mathrm{M}_{\text {intended-non-trial }}=.333, p=$ $\left..225, \mathrm{M}_{\text {unintended-non-trial }}=.613, \mathrm{p}=.003, \mathrm{M}_{\text {intended-unintended }}=-.29, p=.319\right)$.

The results relating to purchase intention differ for the product and the brand. First, we found no significant main effects of the manipulations on product purchase intention or WOM, leading us to reject $\mathrm{H} 1(\mathrm{c}, \mathrm{e})$ (Product purchase intention: $\mathrm{M}_{\text {non-trial }}=4.37, \mathrm{M}_{\text {intended }}=$ $4.09 ; \mathrm{M}_{\text {unintended }}=5.57, \mathrm{~F}(2,140)=1.486, p=.230 ;$ WOM: $\mathrm{M}_{\text {non-trial }}=4.53, \mathrm{M}_{\text {intended }}=4.38 ;$ $\left.\mathrm{M}_{\text {unintended }}=4.76, \mathrm{~F}(2,140)=.491, p=.743\right)$. Rejecting these main effects also led us to 
reject the derived hypothesis regarding the paired comparisons between the groups $(\mathrm{H} 3(\mathrm{c}, \mathrm{e})$ and $\mathrm{H} 4(\mathrm{c}, \mathrm{e}))$. Although the purchase intention for the product was not affected by the manipulation, the brand purchase intention was, since the results showed a significant main effect of the manipulations, confirming $\mathrm{H} 1(\mathrm{~d})\left(\mathrm{M}_{\text {non-trial }}=4.32, \mathrm{M}_{\text {intended }}=4.25\right.$; $\left.\mathrm{M}_{\text {unintended }}=4.82, \mathrm{~F}(2,140)=3.732, p=.026\right)$, whereas the pairwise comparisons show a significantly stronger impact from an intended trial on brand purchase intention compared to a non-trial $(\mathrm{H} 3(\mathrm{~d}))$, and a stronger impact of an unintended trial compared to an intended trial $(\mathrm{H} 4(\mathrm{~d}))\left(\mathrm{M}_{\text {intended-non-trial }}=-.029, p=1.0, \mathrm{M}_{\text {unintended-non-trial }}=.546, p=.071, \mathrm{M}_{\text {intended-unintended }}=-\right.$ $.575, p=.049)$.

Next, by using the PROCESS Macro model 1 for SPSS provided by Hayes (2013), we tested the moderating effect that product involvement (H5) has on the impact of the (un)intended trial information on product attitude and product purchase intention as well as on product-related WOM. For this, we first dichotomized our independent variable, differentiating between intended and unintended trials. We then ran regressions showing that product involvement had a non-significant main effect as well as a non-significant moderating effect on all dependent variables, and therefore, we do not find support for H5(ac) (product attitude: $\beta=.11, p=.258 ; \beta=.086, p=.291$ (H5a), product purchase intention: $\beta$ $=.62, p=.782 ; \beta=.053, p=.279$ (H5b), WOM: $\beta=.739, p=.897 ; \beta=.093, p=.331$ $(\mathrm{H} 5 \mathrm{c}))$. This is partly in line with the results from Study 1, in which involvement had either no effect or a negative effect. These results will be discussed in the following section.

\section{Discussion and Implications}

Even as ABS have increased in importance, research has generally neglected the consequences of such access-based product usage, i.e., unintended trials for promotional purposes from product-brand companies. Our research contributes primarily to three streams of literature: the literature on trials, on IIT and on ABS. 


\section{Discussion and theoretical contributions}

This study contributes to the existing literature in the following main ways. First, this study expands the literature on trials and their role in the adoption of new products. Intended (e.g., test drives) as opposed to unintended (e.g., ABS usage) trials are usually embedded in specific decision-making processes, for which consumers seek experiences and are accordingly goal-oriented and open to information. However, the concomitant experiences of consumers gained through ABS also spill over into evaluations of the brand and product.

Despite their differences, unintended and intended trials thus have similar effects on consumer attitudes, and partially on behaviors. Introducing a new product through ABS spreads information and has a trial effect that alters consumers' perceptions of the product. Interestingly, and opposing hypothesis $\mathrm{H} 4(\mathrm{~d})$, the trial effect on brand purchase intentions is even stronger for unintended trials than for intended trials. This might be due to the different sources of information within the evaluation process. Even though both trial experiences are direct and contain the same information during the intended trial, the consumer is expecting sales-related information from the car dealer, and the provider might thereby be perceived as a biased source of information (Kotler \& Keller, 2015), so that the trial experience could be perceived as less authentic and consequently a less credible source of information. This is in contrast to the ABS provider as a third party who is expected to only provide a service with a product as a means of transportation and not to promote this product, as he offers temporary access but no purchase opportunity. This research accordingly enriches the trial literature by investigating the role of a third-party service provider and identifying ABS as a way to promote new products through unintended trials. In particular, in the field study (Study 1), the personal trial experience influenced consumers to promote the product in the form of positive WOM, which drives the wider diffusion of the product (Zhang et al., 2011). This is 
important because prior research has shown that WOM from consumers with a higher level of expertise — such as after an e-car trial—is impactful (Wangenheim \& Bayón, 2004).

Second, this study contributes to IIT by investigating the situational impact on information integration, or to be more precise, differences in consumers' evaluative mindset (having the intention or not to integrate information) in a particular consumption situation. Interestingly, our results show that for new products, trial information integration does not depend on the evaluative mindset, as consumers obtaining information as a by-product of product use (unintended trial) did not significantly differ from consumers obtaining information through an active search (intended trial), but these personal trial experiences do differ from information obtained from a leaflet describing someone else's experience. Taking these arguments together, we thus conclude that this research suggests that IIT is applicable to settings in which information is not actively sought, such as in intended trials and product tests, but is incidentally acquired.

Third, this research responds to calls for research on the trial effects of ABS (Lawson et al., 2016), what we called positive spillover effects. Previous research has shown that the person-object relationship is weaker in ABS consumption settings compared with ownership (Bardhi \& Eckhardt, 2012; Belk, 2014). However, the current study still shows that using an innovative new product in a before- and after-trial research design (Study 1) and in a study comparing and contrasting non-trial information, intended trials, and unintended trials (Study 2) confirms the predicted but insufficiently empirically tested effect of the positive spillover effects of unintended trials on changing attitudes and behavior. Our results from the field experiment and the online experiment showed positive spillover effects on product and brand attitude $(\mathrm{H} 1(\mathrm{a}, \mathrm{b}))$ and brand purchase intention $(\mathrm{H} 1(\mathrm{~d}))$. The effects on product purchase intention (H1(c)) and WOM (H1(e)) were mixed. While we did not find an effect on product purchase intention in either of the studies, in the field study we found an effect from trial 
experience on WOM but not in the online experiment. We attribute this to e-cars being subject to consumer concerns of limited range and charging infrastructure, while the spreading of positive WOM is perceived as beneficial due to the social desirability of ecological awareness (Wolinetz \& Axsen, 2017; Zhang, Gensler, \& Garcia, 2011). Furthermore, a "real" experience of driving the e-car during the field experiment might be perceived as more prominent and thus more impactful on spreading WOM than an artificially manipulated experience in the online experiment. Moreover, it is interesting that we found effects on brand purchase intention, but not on product purchase intention. This might be due to the product category being a substantially more concrete variable than the brand. As car purchases include extensive information searches, involve high monetary risk, and depend on various factors (Bayus, 1991; Ratchford, Lee, \& Talukdar, 2003), asking for the purchase intention of a tangible product is likely to be further advanced in the decision-making process than asking for the purchase intention of a brand.

This research also contributes to IIT by investigating moderating effects, whereby both moderators were deduced from IIT operationalizing the evaluation of a trial experience as a proxy for the valence of the information, while involvement provided a proxy for their importance or weight. The findings partly support the impact of trial experience in information-integration processes. However, in both studies, we found that involvement seems to have a somewhat ambivalent role in trials of new products. Previous literature in purchase-decision processes, including intended trials, suggests that high involvement leads to positive outcomes (e.g., greater purchase probability) (Lin \& Chen, 2006; Mazodier \& Merunka, 2014). Conversely, Study 1 and Study 2 provided evidence that high involvement either has no effect (Study 1 and 2) or even a weakening effect (Study 1) on the positive effects of unintended trials on attitude, purchase intention, and WOM. With this finding, we contribute to IIT and the stream of literature that treats involvement as a 
consumer predisposition that influences how they process information about a future consumption activity. Specifically, it reveals some unexpected effects of involvement, such as the finding that usage has a weaker effect on both attitude and WOM changes among highly involved consumers (Study 1).

A possible explanation for this unexpected result (which also contradicts IIT) is that consumers who are not involved with a new product or technology profit more from unintended trials. They are not familiar with the new product (or perhaps not interested in, or prejudiced against, it), and therefore an experience may have more impact in terms of reducing potential concerns and generating attention. This is in line with the findings of Heslin and Johnson (1992), suggesting that highly involved people might have a lower need for information. This point represents a clear distinction from the outcomes of intended, goaloriented trials, where the intention to engage in a trial suggests a minimum of involvement, and consequent willingness to engage in the effort.

\section{Managerial implications}

\section{Spillover effect}

The results offer relevant implications for managers. Most importantly, we support the notion that unintended product trials during ABS have positive spillover effects on consumer attitude and behavioral intentions, not only toward the product but also toward the brand. Both studies generally demonstrate positive spillover effects on attitude and partly on behavioral intention; hence, manufacturers can use ABS to promote new products, such as ecars, and their brands, since this channel helps drive their diffusion.

\section{Attitude versus behavior}

We concluded that positive spillover effects in general are evident, in particular on attitude, but that the effects on behavioral intention are mixed. The effects are therefore not as pronounced as predicted. Generally, positive consumer attitudes lead to matching subsequent 
behavior, such as increased purchase intention. However, in this study, a single use or trial experience did not impact subsequent intentions to buy the new product. Three reasons for this outcome seem probable. Firstly, factors beyond attitude, such as the price, affect consumer adoption (Claudy, Garcia, \& O’Driscoll, 2015). Secondly, this finding might reflect an attitude-adoption gap (Rogers, 2003). Thirdly, a single use might be sufficient to influence attitudes and communication behavior (e.g., WOM) but not enough to influence intentions to buy the product. Brands might therefore seek ways to encourage repeated trials, yet ABS still drive intentions to purchase the brand, rather than its new product (e-car) specifically. Marketers should be aware of this brand-promoting effect of ABS and use it to their benefit.

\section{Personal versus non-personal experience}

Our results further show that, with some exceptions, personal as opposed to nonpersonal experiences in trials of new products are very important for consumer attitude and intention formation. Study 2 compared information gathered during trials involving a personal experience (e.g., test drives and ABS) with more traditional types of information gathered through advertising (e.g., leaflets). The results showed that product and brand attitude as well as brand purchase intention are more affected by personal experiences compared to seeing the same information in a leaflet. In contrast, for product purchase intention and WOM, the source of information did not make a difference, leading us to conclude that more abstract attitudes and brand purchase intention on the brand level benefit more from these personal experiences. However, for the more concrete variables such as the intention to speak about the experience with a certain product (WOM) or to purchase the product tested (product purchase intention), it did not make a difference whether the experience was personal or described in the leaflet. For managers, this might mean that spillover effects from ABS are hard to quantify in actual sales figures of products, despite the brand benefiting from them. 


\section{Trial experience}

The results of this study show that the effects of the information about the product gathered in the trial are even more impactful when the experience with a third-party provider is positive, in particular for changes in attitudes and WOM. If brands want to use ABS to improve attitudes toward their new products, they must ensure a positive service experience - even if provided by a third party. Several promising options include offering such a service in-house (such as WeShare by VW) or collaborating with the independent service providers to ensure that the processes are well-designed and that the service is reliable (e.g., sufficiently charged e-cars, helpful user instructions, etc.). This finding is important because brands often have limited control over the service and corresponding trial experience during ABS since it is usually provided by an independent service provider. In view of this, we recommend to brand firms that they choose their partners with care.

\section{Involvement}

In our study, access to a new product (here an e-car) improves product attitudes. However, a consumer's high involvement leads to either no or less pronounced changes in both attitudes and positive WOM. Consumers who are highly involved with an innovation or a new technology might already have realistic expectations, such that it is less likely that they will be impressed by actual usage. Brands that rely on ABS as a strategy to promote new products should therefore target consumer segments that exhibit rather low involvement to generate such a positive "surprise effect". Doing so can increase the chances of changing consumers' attitudes toward the new product and of generating more positive WOM.

\section{Limitations and Directions for Further Research}

These results must be viewed in light of their limitations. Our research examines the impact of ABS usage on attitudes and behavior (purchase intention and WOM). Behavioral intentions are well established as outcome variables in adoption research (e.g., Ma et al., 
2015), but they are still imperfect substitutes for actual behavior (e.g., Arts, Frambach, \& Bijmolt, 2011). Research should thus investigate with more longitudinal data what role ABS play in the trajectory of a purchase decision. Furthermore, the antecedents of behaviors such as WOM are not limited to experiences but can include, for example, personal traits (Berger, 2014). In light of this, future research should address contextual antecedents of WOM that have attracted attention in research on ABS (e.g., self-concept).

In relation to the above, this research demonstrates that ABS drive mainly attitudes rather than purchase intentions. Continued research should address this issue and investigate whether more than one unintended product trial would also have a stronger impact on purchase intention. Contrasting our results with those of Schaefers et al. (2016), who found that continuous usage of a car-sharing program in general leads to lower probability of car ownership, hints at a potential non-linear effect of usage on purchase intention or ownership probability, which is an interesting avenue for further research.

The sample size in Study 1 is limited - even if this is typical in field studies with more than one point of data collection (He et al., 2016) and an actual usage of the product/ brand. Further research might replicate the findings with larger samples, more time points, and additional product categories or brands, also extending it to products other than new ones. Another interesting route might be to research the perceptual changes that result from the use of peer-to-peer platforms, such as getaround.

Furthermore, the participants in Study 1 were provided with an incentive related to usage of the ABS service, while participants in Study 2 were compensated independently. While we did not find evidence that this factor impacted our results, we acknowledge this potential limitation and encourage future research to replicate the findings.

In addition, this study focuses on the impact of product involvement in unintended trials. However, this does not acknowledge differentiations between situational and enduring 
involvement (e.g., Eisend, 2013) as it would have exceeded the scope of this paper. We accordingly propose extending the concept of unintended trials by further investigating the impact of different forms of involvement on the IIT process.

Finally, this study focused on changes in consumers' perceptions after an unintended trial during ABS and reveals primarily a positive spillover effect of trial experience. However, the investigation of negative spillover effects for the brand (e.g., after a service failure by the service provider), especially considering a negativity bias (Chen \& Lurie, 2013) and particular impacts on WOM (Krishen, 2018), represent relevant directions for further research. Overall, studying the effects of changes in consumers' perceptions driven by ABS provides interesting avenues for research and has potentially important implications for managers. 


\section{References}

Abrate, G., \& Viglia, G. (2019). Personal or product reputation? Optimizing revenues in the sharing economy. Journal of Travel Research, 58(1), 136-148. https://doi.org/10.1177/0047287517741998

Akbar, P., Mai, R., \& Hoffmann, S. (2016). When do materialistic consumers join commercial sharing systems. Journal of Business Research, 69(10), 4215-4224. https://doi.org/10.1016/j.jbusres.2016.03.003

Anderson, N. H. (1971). Integration theory and attitude change. Psychological Review, 78(3), 171-206. https://doi.org/10.1037/h0030834

Anderson, N. H. (1981). Foundations of information integration theory. New York: Academic Press.

Anderson, N. H. (1991). Contributions to information integration theory: Volume I: Cognition. Hillsdale, New Jersey: L. Erlbaum Associates.

Arts, J. W. C., Frambach, R. T., \& Bijmolt, T. H. A. (2011). Generalizations on consumer innovation adoption: A meta-analysis on drivers of intention and behavior. International Journal of Research in Marketing, 28(2), 134-144. https://doi.org/10.1016/j.ijresmar.2010.11.002

Bardhi, F., \& Eckhardt, G. M. (2012). Access-Based Consumption: The Case of Car Sharing. Journal of Consumer Research, 39(4), 881-898. https://doi.org/10.1086/666376

Baumeister, C., Scherer, A., \& Wangenheim, F. von (2015). Branding access offers: The importance of product brands, ownership status, and spillover effects to parent brands. Journal of the Academy of Marketing Science, 43(5), 574-588. https://doi.org/10.1007/s11747-015-0440-y

Bayus, B. L. (1991). The consumer durable replacement buyer. Journal of Marketing, 55(1), 42-51. https://doi.org/10.1177/002224299105500104

Beatty, S. E., \& Talpade, S. (1994). Adolescent Influence in Family Decision Making: A Replication with Extension. Journal of Consumer Research, 21(2), 332-341. https://doi.org/10.1086/209401

Bednall, D. H.B., Oppewal, H., Laochumnanvanit, K., \& Nguyen, C. (2018). A trial engagement?: Innovative free and other service trials. Journal of Services Marketing, 32(1), 46-56. https://doi.org/10.1108/JSM-12-2016-0420 
Belk, R. (2014). You are what you can access: Sharing and collaborative consumption online. Journal of Business Research, 67(8), 1595-1600.

https://doi.org/10.1016/j.jbusres.2013.10.001

Benoit, S., Baker, T. L., Bolton, R. N., Gruber, T., \& Kandampully, J. (2017). A triadic framework for collaborative consumption (CC): Motives, activities and resources \& capabilities of actors. Journal of Business Research, 79, 219-227.

https://doi.org/10.1016/j.jbusres.2017.05.004

Berger, J. (2014). Word of mouth and interpersonal communication: A review and directions for future research. Journal of Consumer Psychology, 24(4), 586-607. https://doi.org/10.1016/j.jcps.2014.05.002

Bergkvist, L., \& Rossiter, J. R. (2007). The Predictive Validity of Multiple-Item Versus Single-Item Measures of the Same Constructs. Journal of Marketing Research, 44(2), 175-184. https://doi.org/10.1509/jmkr.44.2.175

Bettiga, D., Lamberti, L., \& Noci, G. (2017). Do mind and body agree? Unconscious versus conscious arousal in product attitude formation. Journal of Business Research, 75, 108117. https://doi.org/10.1016/j.jbusres.2017.02.008

Brown, T. J., Barry, T. E., Dacin, P. A., \& Gunst, R. F. (2005). Spreading the Word: Investigating Antecedents of Consumers' Positive Word-of-Mouth Intentions and Behaviors in a Retailing Context. Journal of the Academy of Marketing Science, 33(2), 123-138. https://doi.org/10.1177/0092070304268417

Carlson, B. D., \& White, M. A. (2008). Enhancing stimulus integration in a consumer information processing system: A theoretical foundation. Marketing Management Journal, $18(2), 154-167$.

Celsi, R. L., \& Olson, J. C. (1988). The Role of Involvement in Attention and Comprehension Processes. Journal of Consumer Research, 15(2), 210-224. https://doi.org/10.1086/209158

Chang, C. (2004). The Interplay of Product Class Knowledge and Trial Experience in Attitude Formation. Journal of Advertising, 33(1), 83-92. https://doi.org/10.1080/00913367.2004.10639156

Chen, Z., \& Lurie, N. H. (2013). Temporal contiguity and negativity bias in the impact of online word of mouth. Journal of Marketing Research, 50(4), 463-476. https://doi.org/10.1509/jmr.12.0063 
Claudy, M. C., Garcia, R., \& O’Driscoll, A. (2015). Consumer resistance to innovation - a behavioral reasoning perspective. Journal of the Academy of Marketing Science, 43(4), 528-544. https://doi.org/10.1007/s11747-014-0399-0

Cohen, J. (1988). Statistical Power Analysis for the Behavioral Sciences. (2 $2^{\text {nd }}$ ed.). Hillsdale, NJ: Erlbaum.

Cui, A. S., \& O'Connor, G. (2012). Alliance portfolio resource diversity and firm innovation. Journal of Marketing, 76(4), 24-43. https://doi.org/10.1509/jm.11.0130

Daugherty, T., Li, H., \& Biocca, F. (2008). Consumer learning and the effects of virtual experience relative to indirect and direct product experience. Psychology and Marketing, 25(7), 568-586. https://doi.org/10.1002/mar.20225

Davidson, A., Habibi, M. R., \& Laroche, M. (2018). Materialism and the sharing economy: A cross-cultural study of American and Indian consumers. Journal of Business Research, 82, 364-372. https://doi.org/10.1016/j.jbusres.2015.07.045

De Angelis, M., Bonezzi, A., Peluso, A. M., Rucker, D. D., \& Costabile, M. (2012). On braggarts and gossips: A self-enhancement account of word-of-mouth generation and transmission. Journal of Marketing Research, 49(4), 551-563.

https://doi.org/10.1509/jmr.11.0136

Dholakia, U. M. (2001). A motivational process model of product involvement and consumer risk perception. European Journal of Marketing, 35(11/12), 1340-1362. https://doi.org/10.1108/EUM0000000006479

Dijksterhuis, A., Smith, P. K., van Baaren, R. B., \& Wigboldus, D. H. J. (2005). The unconscious consumer: Effects of environment on consumer behavior. Journal of Consumer Psychology, 15(3), 193-202. https://doi.org/10.1207/s15327663jcp1503_3

Dodds, W. B., Monroe, K. B., \& Grewal, D. (1991). Effects of Price, Brand, and Store Information on Buyers' Product Evaluations. Journal of Marketing Research, 28(3), 307319. https://doi.org/10.2307/3172866

Eisend, M. (2013). The moderating influence of involvement on two-sided advertising effects. Psychology \& Marketing, 30(7), 566-575. https://doi.org/10.1002/mar.20628

Faul, F., Erdfelder, E., Buchner, A., \& Lang, A.-G. (2009). Statistical power analyses using G*Power 3.1: Tests for correlation and regression analyses. Behavior Research Methods, 41(4), 1149-1160. https://doi.org/10.3758/BRM.41.4.1149

Ferraro, R., Bettman, J. R., \& Chartrand, T. L. (2008). The power of strangers: The effect of incidental consumer brand encounters on brand choice. Journal of Consumer Research, 35(5), 729-741. https://doi.org/10.1086/592944 
Fink, M., Koller, M., Gartner, J., Floh, A., \& Harms, R. (2018). Effective entrepreneurial marketing on Facebook-A longitudinal study. Journal of Business Research. https://doi.org/10.1016/j.jbusres.2018.10.005

Fisher, M., Newman, G. E., \& Dhar, R. (2018). Seeing stars: How the binary bias distorts the interpretation of customer ratings. Journal of Consumer Research, 45(3), 471-489. https://doi.org/10.1093/jcr/ucy017

Gefen, D. (2000). E-commerce: the role of familiarity and trust. Omega, 28(6), 725-737. https://doi.org/10.1016/S0305-0483(00)00021-9

Gershoff, A. D., Mukherjee, A., \& Mukhopadhyay, A. (2003). Consumer acceptance of online agent advice: Extremity and positivity effects. Journal of Consumer Psychology, 13(1-2), 161-170. https://doi.org/10.1207/S15327663JCP13-1\&2_14

Ghosh, T. (2016). Winning Versus not Losing: Exploring the Effects of In-Game Advertising Outcome on its Effectiveness. Journal of Interactive Marketing, 36, 134-147. https://doi.org/10.1016/j.intmar.2016.05.003

Grace, D., \& O’Cass, A. (2004). Examining service experiences and post-consumption evaluations. Journal of Services Marketing, 18(6), 450-461. https://doi.org/10.1108/08876040410557230

Hamilton, R. W., \& Thompson, D. V. (2007). Is there a substitute for direct experience? Comparing consumers' preferences after direct and indirect product experiences. Journal of Consumer Research, 34(4), 546-555. https://doi.org/10.1086/520073

Hastak, M., \& Hong, S.-T. (1991). Country-of-origin effects on product quality judgments: An information integration perspective. Psychology and Marketing, 8(2), 129-143. https://doi.org/10.1002/mar.4220080205

Hayes, A. F. (2013). Introduction to mediation, moderation, and conditional process analysis: A regression-based approach. New York: Guilford Press.

Hazée, S., Delcourt, C., \& Van Vaerenbergh, Y. (2017). Burdens of Access: Understanding Customer Barriers and Barrier-Attenuating Practices in Access-Based Services. Journal of Service Research, 20(4), 441-456. https://doi.org/10.1177/1094670517712877

Hazée, S., Van Vaerenbergh, Y., Delcourt, C., \& Warlop, L. (2019). Sharing Goods? Yuck, No! An Investigation of Consumers' Contamination Concerns About Access-Based Services. Journal of Service Research, 22(3), 256-271.

\section{https://doi.org/10.1177/1094670519838622}


He, Y., Chen, Q., \& Alden, D. L. (2016). Time will tell: Managing post-purchase changes in brand attitude. Journal of the Academy of Marketing Science, 44(6), 791-805. https://doi.org/10.1007/s11747-015-0444-7

Heslin, R., \& Johnson, B. T. (1992). Prior involvement and incentives to pay attention to information. Psychology and Marketing, 9(3), 209-219. https://doi.org/10.1002/mar.4220090304

Hinsz, V. B., \& Ployhart, R. E. (1998). Trying, Intentions, and the Processes by Which Goals Influence Performance: An Empirical Test of the Theory of Goal Pursuit 1. Journal of Applied Social Psychology, 28(12), 1051-1066. https://doi.org/10.1111/j.15591816.1998.tb01667.x

Iyengar, R., van den Bulte, C., \& Lee, J. Y. (2015). Social Contagion in New Product Trial and Repeat. Marketing Science, 34(3), 408-429. https://doi.org/10.1287/mksc.2014.0888

Janiszewski, C., \& Cunha Jr, M. (2004). The influence of price discount framing on the evaluation of a product bundle. Journal of Consumer Research, 30(4), 534-546. https://doi.org/10.1086/380287

Kardes, F. R., \& Kalyanaram, G. (1992). Order-of-entry effects on consumer memory and judgment: An information integration perspective. Journal of Marketing Research, 29(3), 343-357. https://doi.org/10.1177/002224379202900305

Keller, K. L., \& Aaker, D. A. (1992). The effects of sequential introduction of brand extensions. Journal of Marketing Research, 29(1), 35-50. https://doi.org/10.1177/002224379202900104

Kempf, D. S. (1999). Attitude formation from product trial: Distinct Roles of Cognition and Affect for Hedonic and Functional Products. Psychology \& Marketing, 16(1), 35-50. https://doi.org/10.1002/(SICI)1520-6793(199901)16:1<35::AID-MAR3>3.0.CO;2-U

Kempf, D. S., \& Laczniak, R. N. (2001). Advertising's influence on subsequent product trial processing. Journal of Advertising, 30(3), 27-38. https://doi.org/10.1080/00913367.2001.10673643

Kempf, D. S., Laczniak, R. N., \& Smith, R. E. (2006). The effects of gender on processing advertising and product trial information. Marketing Letters, 17(1), 5-16. https://doi.org/10.1007/s11002-006-3545-8

Kempf, D. S., \& Smith, R. E. (1998). Consumer processing of product trial and the influence of prior advertising: A structural modeling approach. Journal of Marketing Research, 35(3), 325-338. https://doi.org/10.1177/002224379803500304 
Kim, J., \& Morris, J. D. (2007). The Power Of Affective Response And Cognitive Structure In Product-Trial Attitude Formation. Journal of Advertising, 36(1), 95-106. https://doi.org/10.2753/JOA0091-3367360107

Kim, J., Yoon, H. J., \& Lee, S. Y. (2010). Integrating advertising and publicity. Journal of Advertising, 39(1), 97-114. https://doi.org/10.2753/JOA0091-3367390107

Kotler, P., \& Keller, K. L. (2015). Marketing Management (15 $5^{\text {th }}$ ed.). Harlow: Pearson education.

Krishen, A. S., \& Hu, H.-F. (2018). Will they pitch or will they switch? Comparing Chinese and American consumers. Psychology and Marketing, 35(3), 210-219. https://doi.org/10.1002/mar.21081

Lamberton, C. P., \& Rose, R. L. (2012). When Is Ours Better Than Mine? A Framework for Understanding and Altering Participation in Commercial Sharing Systems. Journal of Marketing, 76(4), 109-125. https://doi.org/10.1509/jm.10.0368

Lawson, S. J., Gleim, M. R., Perren, R., \& Hwang, J. (2016). Freedom from ownership: An exploration of access-based consumption. Journal of Business Research, 69(8), 26152623. https://doi.org/10.1016/j.jbusres.2016.04.021

Leisen Pollack, B. (2017). Effects of exit barriers on word of mouth activities. Journal of Services Marketing, 31(6), 512-526. https://doi.org/10.1108/JSM-01-2016-0024

Lin, L.-Y., \& Chen, C.-S. (2006). The influence of the country-of-origin image, product knowledge and product involvement on consumer purchase decisions: an empirical study of insurance and catering services in Taiwan. Journal of Consumer Marketing, 23(5), 248265. https://doi.org/10.1108/07363760610681655

Lonati, S., Quiroga, B. F., Zehnder, C., \& Antonakis, J. (2018). On doing relevant and rigorous experiments: Review and recommendations. Journal of Operations Management, 64(1), 19-40. https://doi.org/10.1016/j.jom.2018.10.003

Ma, Z., Gill, T., \& Jiang, Y. (2015). Core Versus Peripheral Innovations: The Effect of Innovation Locus on Consumer Adoption of New Products. Journal of Marketing Research, 52(3), 309-324. https://doi.org/10.1509/jmr.13.0337

Malhotra, N., \& Birks, D. (2007). Marketing Research: an applied approach: $3^{\text {rd }}$ European Edition ( $3^{\text {rd }}$ ed.). Harlow: Pearson education.

Maxham III, J. G. (2001). Service recovery's influence on consumer satisfaction, positive word-of-mouth, and purchase intentions. Journal of Business Research, 54(1), 11-24. https://doi.org/10.1016/S0148-2963(00)00114-4 
Mazodier, M., \& Merunka, D. (2014). Beyond brand attitude: Individual drivers of purchase for symbolic cobranded products. Journal of Business Research, 67(7), 1552-1558. https://doi.org/10.1016/j.jbusres.2014.01.015

Micu, C. C., \& Coulter, R. A. (2012). The Impact of Pretrial Advertising on Posttrial Product Evaluations: Assessing the Effects of Attribute Information for Hedonic and Utilitarian Products. Journal of Marketing Theory and Practice, 20(2), 189-202. https://doi.org/10.2753/MTP1069-6679200205

Moeller, S., \& Wittkowski, K. (2010). The burdens of ownership: reasons for preferring renting. Managing Service Quality: An International Journal, 20(2), 176-191. https://doi.org/10.1108/09604521011027598

Mooy, S. C., \& Robben, H. S. J. (2002). Managing consumers' product evaluations through direct product experience. Journal of Product \& Brand Management, 11(7), 432-446. https://doi.org/10.1108/10610420210451625

Morgeson III, F. V., Mithas, S., Keiningham, T. L., \& Aksoy, L. (2011). An investigation of the cross-national determinants of customer satisfaction. Journal of the Academy of Marketing Science, 39(2), 198-215. https://doi.org/10.1007/s11747-010-0232-3

Oyedele, A., \& Simpson, P. (2018). Emerging adulthood, sharing utilities and intention to use sharing services. Journal of Services Marketing, 32(2), 161-174. https://doi.org/10.1108/JSM-09-2016-0344

Packard, G., \& Berger, J. (2017). How language shapes word of mouth's impact. Journal of Marketing Research, 54(4), 572-588. https://doi.org/10.1509/jmr.15.0248

Peterson, R. A., \& Merino, M. C. (2003). Consumer information search behavior and the internet. Psychology and Marketing, 20(2), 99-121. https://doi.org/10.1002/mar.10062

Priluck, R., \& Till, B. D. (2004). The Role of Contingency Awareness, Involvement, and Need for Cognition in Attitude Formation. Journal of the Academy of Marketing Science, 32(3), 329-344. https://doi.org/10.1177/0092070303257646

Ratchford, B. T., Lee, M.-S., \& Talukdar, D. (2003). The impact of the Internet on information search for automobiles. Journal of Marketing Research, 40(2), 193-209. https://doi.org/10.1509/jmkr.40.2.193.19221

Reutershan, J., \& McBroom, G. (2016). What these 3 Auto trends mean for brands. Retrieved from https://www.thinkwithgoogle.com/articles/auto-trends-consumer-behavior.html

Richins, M. L., \& Bloch, P. H. (1986). After the New Wears off: The Temporal Context of Product Involvement. Journal of Consumer Research, 13(2), 280-285. https://doi.org/10.1086/209067 
Rogers, E. M. (2003). Diffusion of innovations ( $5^{\text {th }}$ ed.). New York: Free Press.

Schaefers, T., Lawson, S. J., \& Kukar-Kinney, M. (2016). How the burdens of ownership promote consumer usage of access-based services. Marketing Letters, 27(3), 569-577. https://doi.org/10.1007/s11002-015-9366-X

Schaefers, T., Wittkowski, K., Benoit, S., \& Ferraro, R. (2016). Contagious effects of customer misbehavior in access-based services. Journal of Service Research, 19(1), 3-21. https://doi.org/10.1177/1094670515595047

Schumann, J. H., Wünderlich, N. V., \& Evanschitzky, H. (2014). Spillover Effects of Service Failures in Coalition Loyalty Programs: The Buffering Effect of Special Treatment Benefits. Journal of Retailing, 90(1), 111-118. https://doi.org/10.1016/j.jretai.2013.06.005 Simonin, B. L., \& Ruth, J. A. (1998). Is a Company Known by the Company It Keeps? Assessing the Spillover Effects of Brand Alliances on Consumer Brand Attitudes. Journal of Marketing Research, 35(1), 30-42. https://doi.org/10.2307/3151928

Simonson, I. (2005). In defense of consciousness: The role of conscious and unconscious inputs in consumer choice. Journal of Consumer Psychology, 15(3), 211-217. https://doi.org/10.1207/s15327663jcp1503_5

Smith, R. E. (1993). Integrating Information from Advertising and Trial: Processes and Effects on Consumer Response to Product Information. Journal of Marketing Research, 30(2), 204-219. https://doi.org/10.2307/3172828

Smith, R. E., \& Swinyard, W. R. (1983). Attitude-Behavior Consistency: The Impact of Product Trial versus Advertising. Journal of Marketing Research, 20(3), 257-267. https://doi.org/10.2307/3151829

Suh, J.-C., \& Youjae, Y. (2006). When Brand Attitudes Affect the Customer SatisfactionLoyalty Relation: The Moderating Role of Product Involvement. Journal of Consumer Psychology, 16(2), 145-155. https://doi.org/10.1207/s15327663jcp1602 5

Triantafillidou, A., \& Siomkos, G. (2014). Consumption experience outcomes: Satisfaction, nostalgia intensity, word-of-mouth communication and behavioural intentions. Journal of Consumer Marketing, 31(6/7), 526-540. https://doi.org/10.1108/JCM-05-2014-0982

Tybout, A. M., Sternthal, B., Malaviya, P., Bakamitsos, G. A., \& Park, S.-B. (2005). Information Accessibility as a Moderator of Judgments: The Role of Content versus Retrieval Ease. Journal of Consumer Research, 32(1), 76-85. https://doi.org/10.1086/426617 
Wangenheim, F. v., \& Bayón, T. (2004). The effect of word of mouth on services switching. European Journal of Marketing, 38(9/10), 1173-1185.

\section{https://doi.org/10.1108/03090560410548924}

Wangenheim, F. v., \& Bayón, T. (2007). The chain from customer satisfaction via word-ofmouth referrals to new customer acquisition. Journal of the Academy of Marketing Science, 35(2), 233-249. https://doi.org/10.1007/s11747-007-0037-1

Wien, A. H., \& Olsen, S. O. (2014). Understanding the relationship between individualism and word of mouth: A self-enhancement explanation. Psychology and Marketing, 31(6), 416-425. https://doi.org/10.1002/mar.20704

Wolinetz, M., \& Axsen, J. (2017). How policy can build the plug-in electric vehicle market: Insights from the Respondent-based Preference and Constraints (REPAC) model. Technological Forecasting and Social Change, 117, 238-250.

Wright, A. A., \& Lynch Jr, J. G. (1995). Communication effects of advertising versus direct experience when both search and experience attributes are present. Journal of Consumer Research, 21(4), 708-718. https://doi.org/10.1086/209429

Xu, J., Forman, C., Kim, J. B. [Jun B.], \& Van Ittersum, K. (2014). News Media Channels: Complements or Substitutes? Evidence from Mobile Phone Usage. Journal of Marketing, 78(4), 97-112. https://doi.org/10.1509/jm.13.0198

Zaichkowsky, J. L. (1985). Measuring the Involvement Construct. Journal of Consumer Research, 12(3), 341-352. https://doi.org/10.1086/208520

Zhang, T., Gensler, S., \& Garcia, R. (2011). A Study of the Diffusion of Alternative Fuel Vehicles: An Agent-Based Modeling Approach. Journal of Product Innovation Management, 28(2), 152-168. https://doi.org/10.1111/j.1540-5885.2011.00789.x

Zizzo, D. J. (2010). Experimenter demand effects in economic experiments. Experimental Economics, 13(1), 75-98. https://doi.org/10.1007/s10683-009-9230-Z 
Appendix A: Measures (Studies 1 and 2)

\begin{tabular}{|c|c|c|c|}
\hline Construct & Scale Items & $\begin{array}{l}\text { Cronbach's Alpha, } \\
\text { Study } 1 \text { / Study } 2\end{array}$ & Source \\
\hline $\begin{array}{l}\text { Product } \\
\text { Attitude }\end{array}$ & $\begin{array}{l}\text { Bad/good } \\
\text { Dislike/like } \\
\text { Negative/positive } \\
\text { Unpleasant/pleasant } \\
\text { Poor performance/good performance }\end{array}$ & $\alpha s \geq .87 / .95$ & $\begin{array}{l}\text { Bergkvist } \\
\text { \& Rossiter, 2007; } \\
\text { Tybout et al., } \\
2005\end{array}$ \\
\hline Brand Attitude & $\begin{array}{l}\text { Bad/good } \\
\text { Dislike/like } \\
\text { Unreliable/reliable } \\
\text { Negative/positive } \\
\text { Unpleasant/pleasant }\end{array}$ & $\alpha s \geq .94 / 94$ & $\begin{array}{l}\text { Bergkvist } \\
\text { \& Rossiter, } 2007\end{array}$ \\
\hline $\begin{array}{l}\text { Product } \\
\text { Purchase } \\
\text { Intention }\end{array}$ & $\begin{array}{l}\text { If I were going to buy a car, I would consider buying an e- } \\
\text { car ... } \\
\text { The probability that I would consider buying an e-car is ... } \\
\text { My willingness to buy an e-car is ... } \\
\text { The likelihood of purchasing an e-car in future is ... }\end{array}$ & $\alpha s \geq .83 / 92$ & Dodds et al., 1991 \\
\hline $\begin{array}{l}\text { Brand Purchase } \\
\text { Intention }\end{array}$ & $\begin{array}{l}\text { If I were going to buy a car, I would consider buying a car } \\
\text { of the brand XY. } \\
\text { The probability that I would consider buying a XY is ... } \\
\text { My willingness to buy a car of the brand XY is ... } \\
\text { The likelihood of purchasing a car from the brand XY is ... }\end{array}$ & $\alpha \mathrm{s} \geq .89 / 92$ & Dodds et al., 1991 \\
\hline $\begin{array}{l}\text { WOM about } \\
\text { product }\end{array}$ & $\begin{array}{l}\text { How likely are you to spread positive WOM about e-cars? } \\
\text { I would recommend e-cars to my friends and relatives. } \\
\text { If my friends were looking for a car, I would tell them to try } \\
\text { an e-car. } \\
\text { I would talk to others about the positive aspects of e-cars. }\end{array}$ & $\alpha s \geq .82 / 95$ & Maxham III, 2001 \\
\hline $\begin{array}{l}\text { Trial } \\
\text { Experience } \\
\text { (Study 1) }\end{array}$ & $\begin{array}{l}\text { Bad/good } \\
\text { Unpleasant/pleasant } \\
\text { Unfavorable/favorable } \\
\text { Negative/positive }\end{array}$ & $\alpha=.92 /--$ & Kempf, 1999 \\
\hline $\begin{array}{l}\text { Product } \\
\text { Involvement }\end{array}$ & $\begin{array}{l}\text { In general, I have a strong interest in e-cars. } \\
\text { E-cars are very important to me. } \\
\text { E-cars matter a lot to me. } \\
\text { (Usually) it is exciting when other people talk to me about } \\
\text { e-cars. }\end{array}$ & $\alpha s=.90 / 96$ & $\begin{array}{l}\text { Beatty \& Talpade, } \\
\text { 1994; Ghosh, } \\
2016\end{array}$ \\
\hline $\begin{array}{l}\text { Manipulation } \\
\text { check trial } \\
\text { Experience } \\
\text { (Study 2) }\end{array}$ & Good experience/bad experience & & - \\
\hline $\begin{array}{l}\text { Manipulation } \\
\text { Check ABS } \\
\text { (Study 2) }\end{array}$ & $\begin{array}{l}\text { In the scenario you were asked to imagine that you have } \\
\text { intentionally booked a free test drive } \\
\text { In the scenario you were asked to imagine } \\
\text { using a local car sharing programme } \\
\text { In the scenario you were asked to imagine } \\
\text { reading a leaflet }\end{array}$ & & - \\
\hline $\begin{array}{l}\text { Manipulation } \\
\text { Check } \\
\text { Intention } \\
\text { (Study 2) } \\
\end{array}$ & $\begin{array}{l}\text { I intentionally tried an e-car } \\
\text { I unintentionally tried an e-car } \\
\text { I didn't try an e-car }\end{array}$ & & - \\
\hline $\begin{array}{l}\text { Familiarity } \\
\text { with innovation } \\
\text { (Study 2) }\end{array}$ & I am familiar with electric cars. & & Gefen, 2000 \\
\hline
\end{tabular}




\section{Appendix B: Vignettes (Study 2)}

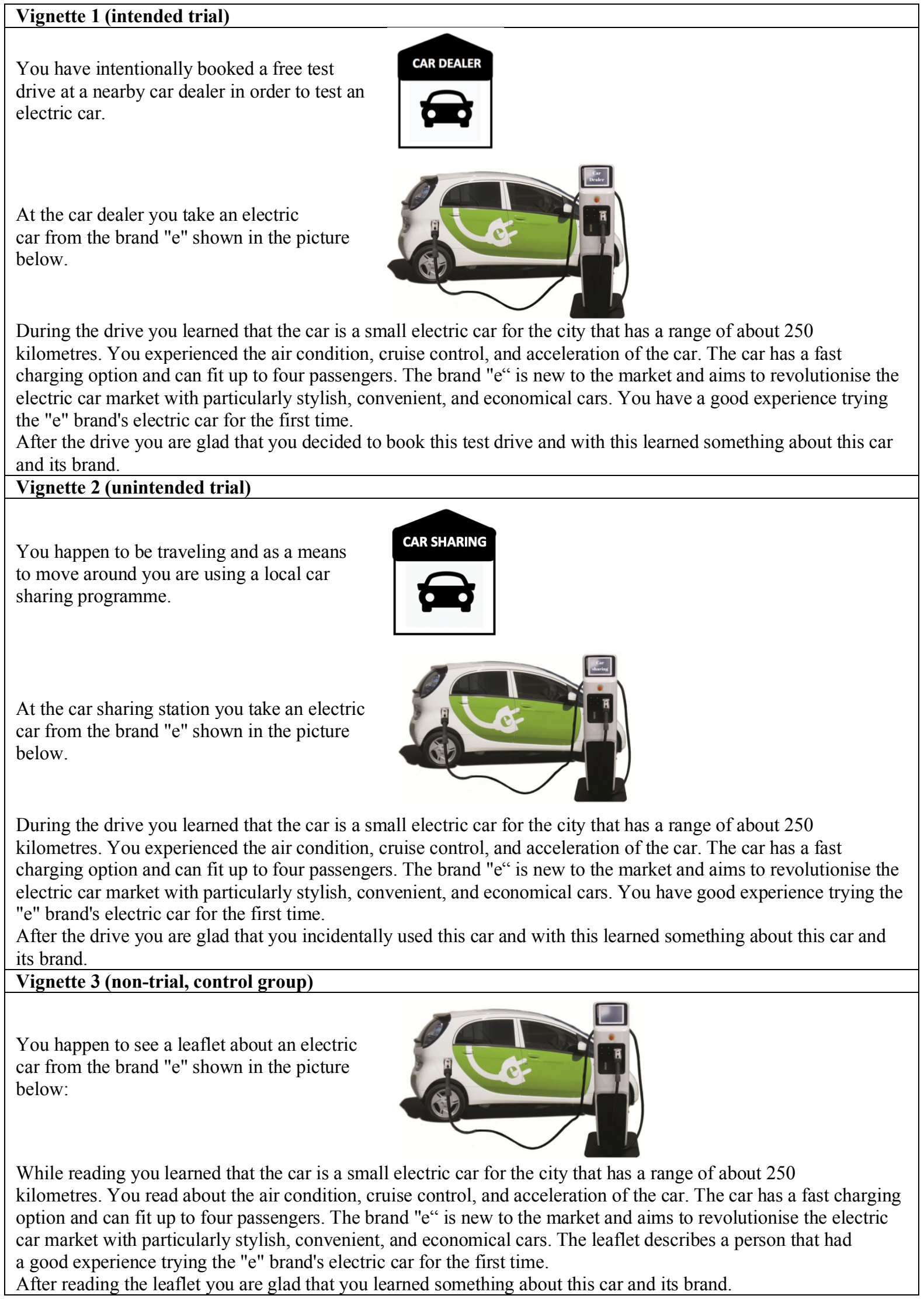

